\title{
Reading leaders' minds: in search of the canon of 21st century global capitalism
}

\author{
Christopher Michaelson
}

Published online: 2 June 2011

(C) Springer Science+Business Media B.V. 2011

\begin{abstract}
This paper explores the values and practices of capitalism and speculates about how they might evolve as twenty-first century global capitalism comes into being. The values embodied by the Westernized canon we have inherited might account for certain shortcomings of capitalism. As economic power shifts away from dominant markets of the recent past, our search for the canon of twenty-first century global capitalism can help shape the values we aspire for our capitalism of the future to embody and to enable.
\end{abstract}

Keywords Business ethics - Corporate social responsibility · Critical theory Economics $\cdot$ Emerging markets $\cdot$ Sustainable development

\section{What books shape the values of today's business leaders?}

In the Alpine village of Davos, Switzerland, each January, the World Economic Forum convenes the largest and possibly most significant gathering of business, political, and academic leaders to discuss and propose solutions to urgent global economic concerns by day and to revel with stars by night. The annual fête juxtaposes pressing tensions within contemporary capitalism: excess and scarcity, wealth and poverty, growth and depletion. The problems coexist at Davos, the elites pledging to help solve them while at the same time being blamed for them. So it might at first appear peculiar - even self-indulgent - that a portion of the Annual Meeting audience in 2010, at a discussion called "Reading Leaders' Minds," was there for a time not to speculate directly about future trade flows, political hotspots, currency fluctuations, and environmental task forces, but rather to have a conversation about books. The session description posed the question: "What classic

C. Michaelson $(\bowtie)$

Opus College of Business, University of St. Thomas, 1000 LaSalle Ave., TMH 443,

Minneapolis, MN 55403, USA

e-mail: cmmichaelson@stthomas.edu 
and contemporary books shape the personal and professional values of today's leaders?" (World Economic Forum 2010a). ${ }^{1}$ Indeed, the problems of the human condition - climate change, poverty, recession - that are analyzed in service to the Forum's overriding commitment "to improving the state of the world," might seem too urgent to submit to a taste for the humanities, arts, and culture. However, the session summary implied that the very foundation of values such texts instill might be critical to our objectives and how to achieve them. The panel suggested that the right books are essential to values formation and thus the way in which we identify, prioritize, and engage in solving issues that promote general well-being.

One panelist claimed to have imagined being accompanied by a Jules Verne or Carl Sagan science fiction character with every hard decision that had to be made. Another spoke of the children's books that were alleged to have been favored by Margaret Thatcher, underscoring the connection between reading, youth, and the familiar and probably accurate claim that our values are significantly formed when we are young. Although "the canon of management literature grows by some 11,000 books a year", the session summary observed, "many...will remain unread on bookshelves" as leaders choose to read instead biography and literature "as a source of comfort and inspiration" that "shapes one's view of the world and provides insights into the human condition beyond direct experience."

This claim of values formation is redolent of the episode of the lobster and the squid in Theodore Dreiser's The Financier (Dreiser 1912/1995), an important passage in this otherwise moralistic, sentimental tale of the financier, Frank Cowperwood. On his walk after school, young Frank passes by a fish market tank containing said lobster and squid, the only citizens in a finite, rectangular, resource-scarce universe from which there is no escape, no Jules Verne submarine or Carl Sagan spaceship with which to transform their existential problem into a growth opportunity (consider us to be the lobsters and squids in a tank of gradually diminishing biodiversity, another prominent theme on the Davos agenda). Instead of combining their limited intellects on a collaborative solution, or wasting away in dignified, empathetic companionship, the two animals instead square off in a kind of ultimate fighting cage match, a battle to the death. It is no contest, of course; unbeknownst to the squid, it has been placed in the tank as food for its armor-clad enemy, becoming a spectacle for passersby, including 10year-old Frank, "witness to a tragedy which stayed with him all his life and cleared things up considerably intellectually" (7). Frank returned daily to see as "small portions of [the squid's] body began to disappear, snapped off by the relentless claws of his pursuer" (8). Eventually, the squid's evasive maneuvering is compromised by its loss of limbs and depleted ink sac, leaving it defenseless against the lobster's final stroke. Seeing "the squid cut in two and partially devoured" (8), Frank waxes Darwinian, reasoning that the lobster will meet its match when it is boiled and eaten by human beings (like the now-extinct Easter

\footnotetext{
${ }^{1}$ In the time period around and including the World Economic Forum panels referenced in this paper, the author provided advice on the Forum's Arts and Culture Programme, an informal role which included input on the referenced panels and suggesting the title, "Reading Leaders' Minds."
} 
Islanders in Jared Diamond's Collapse (Diamond 2005) or the Lorax in Dr. Seuss' Truffala tree forest (Geisel 1971), or ourselves, for that matter, the lobster should not have destroyed its only source of material or spiritual sustenance). "'And what lived on men?' [Frank] asked himself," forming his grim view of competitive capitalism. "'Was it other men?"' (9)

Supposed we read this narrative into the 2008-2009 Wall Street banking debacle, to consider it as a tale of so many lobsters and squid. JP Morgan Chase was ravenous lobster to Bear Stearns' and Washington Mutual's' swallowed-up squids, Wells Fargo to Wachovia's, but perhaps Bank of America gorging itself on Merrill Lynch provides the best analogy. Just when Ken Lewis thought he had consumed (with a glass of champagne) the best investment banking morsel on Wall Street's plate, his investors began gagging on the John Thain bonus fiasco-a devious squid ploy to enjoy one last lavish meal of unearned bonuses - and then begging BofA's government keeper for more Treasury Asset Relief Program sustenance when they found Merrill to contain more toxic flesh than anticipated (Craig et al. 2008; Yousuf 2009). It was only a matter of time until Lewis' shareholders forced him to spit out Thain and ultimately to sacrifice himself.

Of course, we must be careful as with any analogy not to let our imaginations get the best of us-where do bankrupt Lehman and gluttonous Goldman Sachs fit into the story, after all; was Lehman the lobster that the government keepers of the fish allowed to starve while Goldman took more than its fill?-but narrative literature is an especially rich source of value signification. Storytelling is a near universal human means to educate, entertain, and understand ourselves. Poetry has since ancient times been one of the revered occupations of the Chinese literati, while the prominence of poetic drama in ancient Greek society was both a source of debate within Plato's dialogues about the potential corrupting influence of poetry and of conviction within Aristotle's philosophy about the essential role of poetry in shaping the good life. Western intellectual history is largely a history in books, and although the book form is relatively modern and does not have the same historical significance in non-Western societies, cultures in which history and narrative were transmitted through other means are now connected through a global economy to the book (and now, the electronic book). Narrative literature holds clues both to what is valued in general (for example, love, nature, conflict) and, more particularly, to ethical values. And, imaginative license notwithstanding, it is not perhaps too far-fetched to surmise that Wall Street bankers have subsisted on a belief that wealth creation requires natural selection and its narrative of big winners and extinct losers.

Among the Davos panelists, the discussion yielded agreement on four "classics of business literature"-Niccolò Machiavelli's The Prince (1513/1995), Sun Tzu's The Art of War (ca. 500 BC/1994), Adam Smith's The Wealth of Nations (1776/1993), and Charles Darwin's The Origin of Species (1859/2003) — that have influenced the values and practices of capitalism that we have inherited. Each of these books is a complex work belonging to a particular discipline, though susceptible to multiple interpretations when read critically. On this critical path, interpretation takes on a life of its own, beyond the intended meaning of the author, depicting the assumptions and value systems of the practitioners of capitalism, a population whose composition and power relations are already evolving as the twenty-first century progresses. 


\section{What is (in) the capitalist canon?}

The suggestion that there may be a canon of capitalism might be taken to imply that we have a clear and distinct idea of what capitalism is. However, while capitalist markets may in principle share certain structural features-for example, private ownership of the means of production, free market regulation of price and output - the degree to which these features are implemented in practice varies widely between so-called capitalist markets, within those markets over time, and across a purportedly capitalist global economic system. We might oversimplify, at our peril, when we imply that there is such a thing as a uniform set of capitalist values, especially in our complex age of global capitalism in which economic markets and state power vie for supremacy in determining our economic and cultural relations. The search for the capitalist canon is not an attempt to define and articulate the overt features of capitalism once and for all. To the contrary, it is an attempt to grasp the latent values of capitalist practice of the past and to speculate about how they might evolve as twenty-first century global capitalism comes into being.

The Davos session's four business classics represent merely the anecdotal opinion of an elite gathering of powerful capitalists on a particular day. On any other day, another gathering on a less grandiose stage than Davos might have produced a different list, but let us not for that reason discount the value of these four classics as a starting point for discussion. Capitalism tends to heed the voices of the powerful, and is there any obviously better alternative list of four books that exemplifies the dominant values of capitalist practice over the past century? The Wealth of Nations is the only one among the Davos classics to make Business Strategy Review's (2002) "greatest business books of all time," a list headed by Peters and Waterman's In Search of Excellence, perhaps in part because all of these four classics were appropriated from other purposes for business use. It may not matter that none of these four qualify temporally for the "Most Influential Management Books of the 20th Century" (Bedeian and Wren 2001), led by Taylor's Principles of Scientific Management, because enduring cultural influences must stand a longer test of time. Laissez-faire economists may entertain Friedman's Capitalism and Freedom for the list, but some of them have of late gone Keynesian (Cassidy 2010). Capitalists often see Smith as the anti-Marx, but for some historians and political scientists (Arrighi 1994, Harvey 2007, Postone 1993), Marx's Capital contains the preeminent history of capitalism, whereas among sociologists, Weber's Protestant Ethic and the Spirit of Capitalism (Weber 1904/2009) captures the calling to grow capital best. Of late, executives have turned for comfort to Ayn Rand's celebration of captains of industry in Atlas Shrugged (Rand 1957/1992) (Guthrie 2009, Jones 2002), while critics bemoan in vain a return to Bonfire of the Vanities (Wolfe 1987; Sorkin 2008). These are all worthy candidates for the capitalist canon, among many others, to be sure, but we could do worse than the four classics of Davos in scrounging up a bull or a bear's pawful of texts that epitomize the essential values of late twentieth century, Westerndominated capitalism. If we use this list as a starting point to explore the periodic failure of capitalist cultural values to allocate capital and associated well-being in a just manner, we might get somewhere in our quest to improve upon the capitalism we have inherited. 


\section{Canons, cultures, and countercultures}

Every culture has a canon - that set of iconic representations that embody what is authoritative to literacy in that culture. Harold Bloom, in his defense of the Western canon, defines it as "the true art of memory, the authentic foundation for cultural thinking" (Bloom 1994: 34), while Edward Said, in his criticism of Western imperialism, defines culture as "each society's reservoir of the best that has been known and thought" (Said 1993: xiii). In some cultures, canonization bestows formal institutional sanction on a representative of that culture which has earned canonical status. For example, the Four Books (ca. 500 BC/1965) of Confucianism (the Analects of Confucius, the works of Mencius, along with ritual classic selections The Doctrine of the Mean and The Great Learning, not to be confused with the four classics of Davos) have at various points in Chinese history held canonical status, institutionally and culturally. Institutionally, they have been in some historical periods a normatively prescribed foundation for school curricula and a significant part of the content of the required examination system to qualify for government service. The pervasiveness of these texts in institutional learning across jurisdictions and eras has, in turn, solidified their descriptive importance in the Chinese cultural canon, reflecting practiced values even during the Cultural Revolution when they were considered to be countercultural propaganda by the power elites (Fairbank 1992; Jacques 2009; Spence 1990; World Economic Forum 2009b, 2010b).

In music, the canon originated as "the strictest species of imitation" (Apel 1962: 112), rules for performance in the Middle Ages that could "be performed in augmentation or diminution, or perhaps in contrary or in retrograde motion," such that the complexity of the musical piece expanded but still depended fundamentally on an original, canonical melody that was indispensable to the essence of the musical composition (Reese 1959: 11). In the contemporary Catholic Church, canonization of saints is a painstaking process in which a case is made, scrutinized, and proved for particular "lives [that] have been marked by the exercise of heroic virtue" (Beccari 1907). Through philosophy, literature, music, religious practice, and other forms of art and science, even in the age of technology, texts have been for several thousand years the foundation for the transmission of human civilization and culture. Such texts are fundamental even to music of the church which is set to canonical texts, and to religious practice. In Judaism, for example, the center of the textual canon is the Tanakh, which in turn for Christians is a portion of the Biblical canon, whereas for Muslims the Koran is the canonical text. In literature, T.S. Eliot (1920/1950: 4) claimed, "No poet, no artist of any art, has his complete meaning alone," a modest acknowledgement that similarly led Chinese painters traditionally to attribute one's efforts to the predecessor in whose style one paints than to appropriate all of the credit for one's personal creative genius (Cahill 1985).

A canon in the sense that we are exploring has, then, both descriptive and normative aims. Descriptively, it might reflect the values, desirable and undesirable, of the culture we inherit, much as Said (1993) uses nineteenth and twentieth century Western European literature to reveal how embedded into the dominant culture was the imperialist sentiment. In Said's analysis, situated in that post-Cold War global economic hierarchy that has already evolved so much since, the relative economic strength and development of Western European and North American economies was 
built on a largely unexamined moral presumption of the right to colonize peoples perceived to be inferior. The global capitalism we have inherited from the twentieth century is a complex mixture of colonialist traces, Western developed market norms, and the impending transfer of economic power to new economic champions of the twenty-first century.

Normatively, a canon provides the basis for countercultural dialogue and debate. Answering what we want the canon to be and what we do not want it to be enables us to articulate the values we may want and may not want to inhere in this emerging global capitalism. That is to say that a capitalist canon can function as a common language, or, in capitalist terms, a common currency of ethical and economic values (not incidentally, just as a canon can preserve linguistic consistency, a changing canon can be a precursor to a change in the global currency standard, a change being contemplated among G-20 finance ministers today). It is neither inherently conservative - though it can be used to promote cultural stability, as in the case of the Four Books in Chinese government examinations - nor inherently subversivethough Bloom's conservatism is belied by his claim that "the West's greatest writers are subversive of all values, both ours and their own" (Bloom 1994: 28). A canon is potentially interdisciplinary, as is evident in the variety of disciplines represented by the four classics of Davos, but humanistic narrative might have a special priority in cultural representation and formation about power relations. As Said (1993: xii) remarks, "Stories are at the heart of what explorers and novelists say about strange regions of the world; they also become the method colonized people use to assert their own identity and the existence of their own history."

Thus, our search for the canon of twenty-first century global capitalism will signifyto better understand the complex values that we have inherited - and shape - to better define the values we aspire for our capitalism of the future to embody and to enable. Bloom writes, presciently as though the natural selection metaphor belongs here, too, "The Canon, a word religious in its origins, has become a choice among texts struggling with one another for survival" (Bloom 1994: 19).

\section{A starting point of a search for the capitalist canon}

The struggle for cultural survival is of course influenced in part by the struggle for economic supremacy. The prospect, trumpeted by a prestigious Western financial institution, Goldman Sachs, that by 2050 , both China and India-China by 2027 might have surpassed the USA for the title of world's largest GDP (Wilson and Stupnytska 2007) is both noteworthy and, to intentionally evoke Shakespeare, much ado about nothing. Cautious observers will likely cite rising markets' large populations as inevitably sparking their GDP growth, though they may continue to lag behind in GDP per capita with millions in poverty. As Redding and Witt (2007) challenge, "until [key issues] are dealt with, no amount of gyrating around with other issues will produce annual wealth of $\$ 30,000$ per capita" in China. Others will likely herald the GDP title as both symbolically and politically important, pointing to a gradually narrowing gap in GDP per capita and decreasing inequity. In a 2008 CEO survey report by PricewaterhouseCoopers (PricewaterhouseCoopers 2008), diverging relative growth prospects, a function of perhaps both temporary conditions and 
enduring changes, led to a "tale of two worlds" of economic confidence, to intentionally evoke Dickens. ${ }^{2}$ Philosophers and welfare economists will rightly warn that GDP is a poor measure of the overall quality of life (Nussbaum 2010; Nussbaum and Sen 1993; UNDP 2010). Historians, meanwhile, may do well to remind all sides that leadership is temporary and success might be cyclical. After all, this will not be the first time that China and India have led the pack in GDP; they remained the world's two largest economies until at least a century after Adam Smith wrote The Wealth of Nations (Maddison 2006: 184, 214) and by some quality of life measures they were not, at a macro level, at markedly different points on the spectrum in Smith's time (Van Zanden 2001). Their fall from the top was a historical aberration, in the long historical view (Kirby 2010).

As short-sightedly termed "emerging" economies reassert themselves on the global hierarchy, we should be careful not to presume that the values of capitalism past might be the best or the only foundation for global capitalism future. Nor, of course, does any reasonably sophisticated understanding of capitalisms (the extra 's' signifying an extensive literature on varieties of capitalism: for example, Hall and Soskice 2002; Redding and Witt 2007; Whitley 2002) suppose that capitalist values are univocal. If something like this rebalancing of political and economic power is occurring, and we can say with certainty that it is, even if we cannot say with certainty exactly what it is and how it will turn out, then it is worth exploring deep cultural forces beneath the economic surface that represent the values at stake in this power shift.

The four classics of Davos are perhaps more of a reflection of capitalism past than a prescription for capitalism future. Notwithstanding what they might be missing, they form an impressive list in its disciplinary diversity - a tract on political science, a sociological military study, an economic treatise, and a biological theoryreflecting the complexity of influences on capitalist values in particular and on cultural formation in general. The list is also, arguably, temporally and culturally diverse - spanning from ancient China through pre- and post-Enlightenment Europe. It is not gender-balanced, but then neither has been the practice of capitalism, not even in our present age. While it would be overstating their effects to suggest that Smith and Darwin caused the industrial revolution, they were at once products of and influences on the historical forces that brought about recent prosperity in the industrialized world, and in that regard, all four books have undoubtedly been descriptively impactful on the values and practices of capitalism.

In short, there are many good reasons to consider these four texts as a starting point to search for the capitalist canon. But have business leaders read these texts with critical understanding? Have they, for that matter, read them at all? They may know what it means to be and even to employ tactics that are Machiavellian; they may use war and combat images and terminology to describe their competitive mettle; they may claim to be able to see the effects of the invisible hand; and they may speak of business life as a jungle - but these metaphorical remnants of these four classic texts may be argued to be as much symptoms of what has led us to the current crisis of capitalism as they are essential elements of capitalistic success.

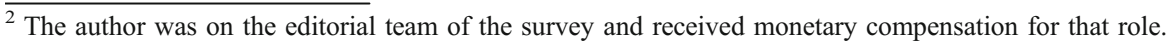


Wall Street, the iconic place of capitalism in the twentieth century, though perhaps no longer its global financial epicenter, is regularly referred to as a Darwinian jungle, in satirical literature (e.g., Wolfe 1987) and critiques (e.g., Solomon 1993), but also in day-to-day parlance by those who do business under the canopy of tall, tree-like skyscrapers, beside the ingrained pillars of the New York Stock Exchange headquarters, and by telephone and online with the traders who pounce like animals on transactions that feed their self-interest. The convenient allegory of survival of the fittest (a phrase coined by Spencer but most often associated with Darwin) becomes our reality, a mechanism not only for descriptive behavior but also for prescriptive practice. The jungle metaphor has come to be accepted by many business leaders as a legitimate construct for business competition, even if we accept certain rules of the game that render our jungle less vicious than in the true state of nature. If Wall Street recedes to the periphery of the global economy, and the jungle metaphor dissipates as well, how might the behaviors and prescriptions of capitalism evolve? Of course, we can only speculate on what the replacements might be "as we move beyond the dichotomies of globalization and localization, developed and developing, capitalism and socialism" ( $\mathrm{Tu}$ 2001a), but it is useful nevertheless to imagine different capitalisms, even if we do not imagine precisely the right ones. The point is that capitalism is not a static doctrine described and prescribed by an unchanging canon but rather a dynamic cultural practice (Appleby 2010), the texts and metaphors of which evolve as well.

So, for example, what if the capitalist jungle leaned a bit more collectivistic than individualistic? After all, in every jungle, there are families and species alliances which confer social protection. Jungle capitalism may often be caricatured as individualistic, but as with the jungle, capitalism is not absolutely individualistic. Individuals may negotiate with, enter, and leave organizations on the basis of selfinterest, but once they belong, they often function with a team-based orientation. Meanwhile, organizations sometimes operate within industry- or geography-based cartels, or with home country allegiances. Collectivism can normatively promote the collective, common good without necessarily requiring adherence to only one collective opinion. Much is made by Western skeptics of how clannishness distorts markets to the detriment of non-members, but clan loyalties might also be credited with the diversion of market benefits to parties with legitimate needs that markets may undervalue.

As with the jungle, so it is with war, that ordinary business parlance and practice is infiltrated with references both playful ("Let's rally the troops!") and serious ("This means war!"), as well as unwitting, as when an expansion into new territories (more military parlance) invokes a timeline for when there will be resources "on the ground" (as though they parachute in as in a military operation). Also like the jungle, the war metaphor is sometimes used to justify antagonistic competitive practice. What The Art of War tells us, among other often forgotten lessons, is that war is not all brute force; in the final section on "employing spies," Sun Tzu declares that in order to successfully deploy spies, a leader must have qualities, among others, including the wisdom of a Sage, benevolence and righteousness, and, above all, subtlety (232). Sun Tzu also advises about double agents, another indication that military organizations involve a complex web of allegiances, as do capitalist systems. When these allegiances conflict-for example, when there is a conflict 
between allegiance to one's brother who is fighting for the other side and one's armya classic conflict of interest erupts as when personal interest conflicts with professional responsibility. Western conflict of interest provisions typically place professional duty ahead of filial piety, though there can be a legitimate debate as to whether strict moral impartiality is always required of us. We may blame the executive for tipping his family and friends before his company's stock price fell with an adverse regulatory decision, but we may at the same time empathize with the (bungled) paternal, compassionate instinct to protect one's own daughter. Western capitalism may demand independence, but this does not preclude the possibility that moral partiality and clan preference could be consistent with emerging capitalisms.

Notwithstanding the tension between moral impartiality and partiality, there is also a question in capitalism as to whether morality itself is always required of us. Machiavelli counseled, "If you take control of a state, you should make a list of all the crimes you have to commit and do them all at once" (30), adding famously that it is better to be feared than loved. Just how prevalent Machiavellian thinking is and just how seriously his counsel has been taken by latter-day capitalists is difficult to ascertain; references to "Machiavellian" tactics are often laced with bemused disapproval. Moreover, there is widespread disagreement on how seriously Machiavelli was meant to be taken. Nevertheless, in the fashion of "murderous Machiavel" (Berlin 1971), acting first and then apologizing later, early industrial capitalists unleashed production methods that had acknowledged adverse local environmental impacts which we have now concluded had aggregate adverse global environmental impacts for which we must now make amends. Analyzing the story in retrospect, early industrialization now appears to have involved a rush to be first to market with production techniques that accelerated particularly Western European and American economic development to the fore of prosperity. Perhaps unwittingly and without intention, they committed the environmental "crimes" to seize control of the global economy, putting power ahead of precaution. Machiavelli's advice about obtaining power was accompanied by advice that benevolent rule was in general the best method for retaining power once obtained. So, when climate change was finally acknowledged to be a global industrial problem requiring collaborative mitigation strategies with the 1994 United Nations Framework Convention on Climate Change, a principle of differentiation was agreed to between developed and developing nations that held the former to higher greenhouse gas emission restrictions in recognition of the century of economic benefits that had accrued to them as a result of having had no restrictions over that period of time. Meanwhile, at the 2009 Copenhagen Climate Change Conference, emerging economies both used their growing economic leverage to negotiate standards while generally urging greater deference to the precautionary principle going forward. China's "ecological turn" has been borne out of economic necessity as well as a "Confucian humanism" that tempers the instrumental rationality of modernization (Tu 2001b).

The temptation to seize power in the short term and to worry later about the longterm consequences is of course at the core of the debate about how effectively the invisible hand works unfettered when market actors are prone to make decisions in their short-term interest with unclear or unknown long-term consequences for themselves and/or potentially for others. In Capitalism and Freedom, Friedman (1962/2002) argued that there was a proper, limited role for government in the 
market economy as "rule-maker and umpire" (25) where there are market imperfections (such as monopolies and externalities) that prevent the market from self-arbitration or when certain market participants incapable of managing their freedom responsibly (namely, madmen and children) require paternalistic intervention. His advocacy of limited government was no doubt shaped by his own timecentric concerns, namely, a global balance of power that teetered between "two alternative ways of organizing an economy: top-down versus bottom-up; central planning and control versus private markets; more colloquially, socialism versus capitalism" (viii). That leaves ample space for us today to ask the question of how paternalistic governments should be when the invisible hand representing the collective economic preferences of market actors might be mistaken.

These sweeping inferences on isolated, metaphorical anecdotes are just that, of course. The inferences may involve debatable presumptions, but the idea itself behind those inferences - that we can derive insights from leaders' cultural preferences about their ethical priorities - is not only logical but also promises opportunities for valuable analysis. When inside a culture in which this sort of metaphorical parlance is commonplace, metaphors become realities in which the participants begin to believe in the normalcy of the behaviors their metaphors promote (Lakoff and Johnson 1980). Beliefs in the ways of capitalism, as a struggle for survival in which an invisible hand infallibly selects the winners, become articles of faith that rational argument cannot undo, that only the narrative, moral imagination can challenge. The iconic metaphors of the four classics may be understood to prioritize methods of distrust, deception, demand, and defeat as antagonistic means to the end of general wealth creation that Smith imagines capitalism bestows. As works of primarily science, none of the four classics unlock the kind of narrative, moral imagination that great works of literature do to incite an appreciation for what is valuable in life beyond what can be measured in financial terms. Understood literally as prescriptive values for capitalist practice, they neither constitute the normative foundations for a humanistic conception of wealth creation for the twenty-first century nor adequately capture the descriptive complexity of the current and emerging balance of economic power.

\section{Research directions in the search for the capitalist canon}

As world leaders and business executives urgently gathered in Davos for the 2009 Annual Meeting to debate "shaping the post-crisis world," not every session on the program was on the economic crisis. To fill out their agendas, attendees' choices included such offerings as, "Leadership Lessons from Shakespeare's Macbeth", a similarly titled session on As You Like It, along with sessions on religious faith, cultural literacy, and youth culture (World Economic Forum 2009a). None of these sessions made the biggest headlines, but their presence on the agenda implies a shared acknowledgement that there are cultural and ethical foundations for business and political relations that warrant ongoing attention and inquiry, even among busy leaders in crisis. The explicit presence of Shakespeare on the agenda and the corresponding absence of any non-Western literature suggest the received judgment of the organizers (who, however, imperfectly represent the received judgment of 
those leaders who thought the meeting worth attending) that the cultural foundations of the preponderance of global economic activity were predominantly Western at that point in time. The presence of the topics that involve changing religious, cultural, and generational values, lacking explicit reference to works of literature, entails that there are other non-economic foundations yet to be associated with any particular enduring cultural icons. Finally, the relative dearth of such topics at all on the September 2008, Tianjin, China, agenda of the WEF's Annual Meeting of the New Champions, might mean that the sense of economic urgency among global growth companies, which are the center of attention at the New Champions meeting, renders reflection on cultural values frivolously impractical.

The ethical and cultural attitudes of business leaders impact not only how they behave but also more fundamental conceptions of what business is for, how it is influenced by human values and influences human well-being. There is, however, no meaningful account of what business leaders read aside from the ephemeral lists of business bestsellers, which compete for executives' time and attention with daily briefings and communications and leave little left for literature. If they had made time in Tianjin in 2008 for literature, what literature would they have chosen? How long will Western classics stay on the Davos agenda, and how much attention will they draw? Whose classics - Russian, Soviet, or foreign - shape the mindset of the Russian manager? What did the American executive read to cram for her first cultural encounter with the Middle East? Are Western Europeans reading colonialist or capitalist manifestos? Do business leaders read more fiction or non-fiction? More about management, history, religion, or biography? Aside from texts, tweets, emails, and PowerPoints, do they read at all? Answers to some or all of these questions would provide unusual opportunities for analysis and insight in a rebalancing global economy which doubtlessly portends a shift in ethical and cultural influence.

To explore the books that might signify and shape this power shift since the global recession, the World Economic Forum has produced four panels, two in 2009 at the Annual Meeting of New Champions in Dalian ("Great Books for a Globalized World" and "Great Books of China"), the 2010 Davos Annual Meeting "Reading Leaders' Minds" panel, and another "Reading Leaders' Minds" panel in 2010 at the Annual Meeting of New Champions in Tianjin. The purpose of these discussions has been to promote a dialogue about canonical texts, not to gather data systematically from which to draw conclusions. However, from these anecdotes and from the author's engagement directly with scholars and practitioners from several continents on the question of what texts have shaped capitalist values, we can reasonably make some conjectures that may guide future descriptive research.

The place of The Wealth of Nations at the center of the capitalist canon is uncontroversial, but not without controversy

It is often the first text to which discussants refer; however, ethics scholars inevitably caveat its inclusion by lamenting that the famed self-interest of the butcher, brewer, and baker has been exaggerated in the popular lore and that Smith's Theory of Moral Sentiments contains a better discussion of the rational limitations of the so-called self-interested behavior. Moreover, some non-Western scholars consider Marx's Das Kapital to provide a better historical account and balanced assessment of how 
capitalism came to be and what its benefits and shortcomings may be. At the 2010 "Reading Leaders' Minds" panel in Tianjin, panelists agreed that "whether in business, politics or civil society, leaders in all fields have to engage more and more across cultures" (World Economic Forum 2010b).

The rest of the capitalist canon is even more controversial

Some practitioners who have experienced the attendant metaphors of the four classics of Davos seem to accept natural selection, combat, and power manipulation as necessary features that guide the invisible hand of capitalism. However, some scholars who perceive these metaphors as having contributed to misconduct, maltreatment, and market failure scoff at these metaphors, claiming that they are insufficient to explain how capitalism benefits general well-being and to guide moral markets. The 2010 "Reading Leaders' Minds" panel at Davos concluded that while designating a "standard list of books" in an increasingly complex global economy might be "virtually impossible," the search was not in vain for "the best leaders are 'complete' people engaged in a deep project of self-improvement" (World Economic Forum 2009b).

Surprisingly little thought has been given to the canon of capitalism future

Audiences tend to agree, on prompting, that a power shift in economic value will be accompanied by a shift in cultural values toward alternative conceptions of wealth creation. However, few have considered what texts, if any, may push The Wealth of Nations toward the periphery of the capitalist canon as the meaning of wealth is reexamined. It is not clear whether those texts have yet to be discovered or if they have yet to be written; the WEF panel on "Great Books of China" and the Tianjin panel on "Reading Leaders' Minds," which both asked specifically about Asian texts, predictably emphasized the importance of Confucian thought in Chinese history, but did not yield particular conclusions about the link to emerging capitalist values. Responding to concerns that capitalism might represent the imposition of Western values on others, "Great Books of China" panelists pointed to the relative historical stability of Chinese cultural foundations, even in the face of repeated foreign aggression and occupation. They concluded that Chinese culture was more likely to appropriate Western capitalist influences into its own cultural framework than to be changed from the outside. "Those who wring their hands over how China can maintain its own cultural canon against an onslaught of Western ideas may be worrying for nothing" (World Economic Forum 2009c).

There are various empirical methods by which the capitalist canon may be descriptively explored

These discussions about the content of the capitalist canon have yielded suggestions about more formal processes for empirical exploration of the capitalist canon.

One set of suggestions focuses on the practitioners of capitalism:

- Survey business leaders on the most influential texts on their personal and professional development as business leaders 
- Analyze the contents of interviews and panels with and biographies of business leaders for references to influential texts

Another set of suggestions looks primarily at business education:

- Identify the most prevalent texts on business school syllabi

- Look at the college majors of business leaders to determine the kinds of educational backgrounds and associated texts that predominate

Still another set of suggestions examines the texts themselves:

- Explore religious and cross-cultural descriptions of commercial activity for implied values and themes

- Examine the presumed core of canonical capitalist texts themselves for crosstextual references

Of course, there are many more possibilities that may be incorporated into any of the above ideas or that may stand alone, including, for example, analyses of government actors, consumers, activists, non-governmental organizations, and other business stakeholders. All of these, with more substantial planning and detail, could be crafted into legitimate research projects unto themselves, and this paper seeks to encourage others to engage in the pursuit of these research directions.

Literature captivates the moral imagination and can and should contribute to future capitalist values formation

From business leaders reminiscing about childhood reading to ethics scholars evaluating Faustian bargains, from Shakespeare appearing as the only literary figure on the 2009 and 2011 Davos Annual Meeting programmes (World Economic Forum 2009a, 2011) to poetry being described as China's "national religion" (World Economic Forum 2009c), literature universally excites passions about personal and professional values and what beyond economic supremacy constitutes wealth. The 2010 Davos panelists concluded that "literature provides a way to shake up thinking, address challenges and forge durable values to guide leaders through the complexities of the 21st century" (World Economic Forum 2010a).

Regrettably, the list of great literature on commercial topics is short. If asked to recommend works of literature to shape normatively the values of future capitalism, I might begin by looking back to Mary Wollstonecraft Shelley's Frankenstein (Shelley 1818/1982), a Gothic horror story about the relentless pursuit of creation without consideration of the consequences - an allegory for unfettered industrialization. Next might be Leo Tolstoy's Master and Man (Tolstoy 1895/2001), the tale of a landowner and his peasant who relentlessly press forward on an ill-fated journey through a snowstorm in hopes of closing the purchase of a grove before competitors arrive - an apt metaphor for excessive risk-taking writ large. Another timely addition might be Abdul Rahman Munif's Cities of Salt (Munif 1984/1989), a powerful if not aesthetically enduring tale of contemporary imperialism told from the points of view of those whose cultures and lives were disrupted by oil speculators. Imaginative literature may seem to be antithetical to the real-world aggressive financial urgency of business, but it may be a valuable source of moral values that can shape capitalism future. 
Acknowledgments The author thanks the following audiences and interlocutors for their valuable feedback and input on aspects of this project: Mireille Bertolini of the World Economic Forum; participants in a law and business ethics research forum at the University of St. Thomas, Minneapolis, 2010; participants in the Paduano Symposium at New York University, Stern School of Business, New York, 2010; participants at the Society for Business Ethics Annual Meeting, Montreal, 2010; and participants at the Third Shanghai International Conference on Business Ethics, Shanghai, 2010. The paper also derived inspiration from discussion among the participants in the Midwest Faculty Seminar on "Global Capitalisms" at the University of Chicago, Chicago, 2010.

\section{References}

Apel, W. (1962). The Harvard dictionary of music. Cambridge: Harvard University Press.

Appleby, J. (2010). The relentless revolution: A history of capitalism. New York: W.W. Norton.

Arrighi, G. (1994). The long twentieth century. New York: Verso.

Beccari, C. (1907). Beatification and canonization. In The Catholic encyclopedia. New York: Robert Appleton Company. Retrieved 17 June 2010 from New Advent: http://www.newadvent.org/cathen/ 02364b.htm.

Bedeian, A. G., \& Wren, D. A. (2001). Most influential management books of the 20th century. Organizational Dynamics, 29(3), 221-225.

Berlin, I. (1971). The question of Machiavelli. New York Review of Books, November 4.

Bloom, H. (1994). The Western canon: The books and school of the ages. New York: Riverhead Books.

Business Strategy Review. (2002). The greatest business books of all time, 13(4), 43-63.

Cahill, J. (1985). Chinese painting. New York: Rizzoli International Publications.

Cassidy, J. (2010). After the blowup: Laissez-faire economists do some soul-searching and fingerpointing. The New Yorker, 85(44), 28-29.

Craig, S., McCracken, J., Lucchetti, A., \& Kelly, K. (2008). The weekend that Wall Street died-Ties that long united strongest firms unraveled as Lehman sank toward failure. Wall Street Journal, 29 December.

Darwin, C. (1859/2003). The origin of species by means of natural selection of the preservation of favoured races in the struggle for life. New York: Signet Classics.

Diamond, J. (2005). Collapse: How societies choose to fail or succeed. New York: Penguin.

Dreiser, T. (1912/1995). The financier. New York: Penguin Books.

Eliot, T. S. (1920/1950). Tradition and the individual talent. In Selected essays 1917-1932 (new edition). New York: Harcourt Brace.

Fairbank, J. K. (1992). China: A new history. Cambridge: The Belknap Press of Harvard University Press. Friedman, M. (1962/2002). Capitalism and freedom. Chicago, Illinois, USA: University of Chicago Press. Geisel, T. S. (1971). The Lorax. New York: Random House (Dr. Seuss).

Guthrie, M. (2009). The book that's in and out of fashion. Financial Times, 13 March.

Hall, P. A., \& Soskice, D. (Eds.). (2002). Varieties of capitalism. Oxford: Oxford University Press.

Harvey, D. (2007). The limits to capital. New York: Verso.

Jacques, M. (2009). When China rules the world: The end of the Western world and the birth of a new global order. New York: Penguin.

Jones, D. (2002). Scandals lead execs to 'Atlas Shrugged'; 1957 Ayn Rand novel sanctions self-interest. USA Today, 24 September.

Kirby, W.C. (2010). China's ascent signals a return to historical norms. Harvard Business Review blog post. Retrieved 18 August 2010 from http://blogs.hbr.org/hbsfaculty/2010/08/chinas-ascent-signals-a-return.html.

Lakoff, G., \& Johnson, M. (1980). Metaphors we live by. Chicago: University of Chicago Press.

Legge, J. (ed. and trans.) (ca. 500 BC/1965). The four books: The great learning, the doctrine of the mean, Confucian analects, and the works of Mencius. Hong Kong: Culture Book Co.

Machiavelli, N. (1513/1995). The Prince (translated by D. Wootton). Indianapolis: Hackett.

Maddison, A. (2006). The world economy: A millennial perspective and historical statistics (2 vols. originally published 2001 and 2003, respectively). Paris: Development Centre of the Organisation for Economic Cooperation and Development.

Munif, A. (1984/1989). Cities of salt (translated by P. Theroux). New York: Vintage Books.

Nussbaum, M. C. (2010). Not for profit: Why democracy needs the humanities. Princeton: Princeton University Press.

Nussbaum, M. C., \& Sen, A. (1993). The quality of life. New York: Oxford University Press. 
Postone, M. (1993). Time, labor, and social domination: A reinterpretation of Marx's critical theory. New York: Cambridge University Press.

PricewaterhouseCoopers. (2008). 11th Annual global CEO survey. Retrieved 31 January 2008 from http:// www.pwc.com/ceosurvey.

Rand, A. (1957/1992). Atlas shrugged. New York: Random House.

Redding, R., \& Witt, M. A. (2007). The future of Chinese capitalism: Choices and chances. New York: Oxford University Press.

Reese, G. (1959). Music in the Renaissance (revised edition). New York: W.W. Norton.

Said, E. W. (1993). Culture and imperialism. New York: Vintage Books.

Shelley, M.W. (1818/1982). Frankenstein, or, the modern Prometheus (edited by James Rieger). Chicago: University of Chicago Press.

Smith, A. (1776/1993). An inquiry into the nature and causes of the wealth of nations (edited by Kathryn Sutherland). Oxford: Oxford University Press.

Solomon, R. C. (1993). Ethics and excellence: Cooperation and integrity in business. New York: Oxford University Press.

Sorkin, A.R. (2008). A 'Bonfire' returns as heartburn. New York Times, 24 June.

Spence, J. (1990). The search for modern China. New York: W.W. Norton.

Sun Tzu. (c. 500 B.C./1994). The art of war (translated by R.D. Sawyer). Boulder: Westview Press.

Tolstoy, L. N. (1895/2001). Master and Man. In Collected Shorter Fiction, v. 2 (translated by L. Maude and A. Maude and N.J. Cooper). New York: Everyman's Library.

Tu, W. (2001a). The ecological turn in new Confucian humanism: Implications for China and the world. Daedelus, 130(4), 243-264.

Tu, W. (2001a). The Confucian perception of religious pluralism: Globalization and diversity. Retrieved 6 June 2010 from http://tuweiming.com/lecture.6.html.

UNDP (United Nations Development Programme). (2010). Human development reports. Retrieved 1 September 2010 from http://hdr.undp.org/en/statistics/.

Van Zanden, J. L. (2001). The great convergence from a West-European perspective: Some thoughts and hypotheses. Itinerario, 24(3-4), 9-29.

Weber, M. (1904/2009). The Protestant ethic and the spirit of capitalism. New York: W.W. Norton.

Whitley, R. (Ed.). (2002). Competing capitalisms: Institutions and economies. Cheltenham: Edward Elgar.

Wilson, D. \& Stupnytska, A. (2007). The N-11: More than an acronym. GS Global Economic Papers (no. 153). Retrieved 31 May 2010 from http:/www2.goldmansachs.com/ideas/global-economic-outlook/ n-11-acronym-doc.pdf.

Wolfe, T. (1987). The bonfire of the vanities. New York: Picador.

World Economic Forum. (2009a). Annual Meeting 2009 programme. Retrieved 1 October 2009 from http://www.weforum.org/en/events/ArchivedEvents/AnnualMeeting2009/Programme/index.htm? date $=$ ALL.

World Economic Forum. (2009b). Great books for a globalized world (session summary). Retrieved 1 October 2009 from http://www.weforum.org/en/knowledge/Events/2009/AnnualMeetingoftheNewChampions/ KN_SESS_SUMM_29205?url=/en/knowledge/Events/2009/AnnualMeetingoftheNewChampions/ KN_SESS_SUMM_29205.

World Economic Forum. (2009c). Great books of China (session summary). Retrieved 1 October 2009 from http://www.weforum.org/en/knowledge/Events/2009/AnnualMeetingoftheNewChampions/ KN_SESS_SUMM_29356?url=/en/knowledge/Events/2009/AnnualMeetingoftheNewChampions/ KN_SESS_SUMM_29356.

World Economic Forum. (2010a). Reading leaders' minds (session summary). Retrieved 26 February 2010 from http://www.weforum.org/en/knowledge/Events/2010/AnnualMeeting/KN_SESS_SUMM_30140? url=/en/knowledge/Events/2010/AnnualMeeting/KN_SESS_SUMM_30140.

World Economic Forum. (2010b). Reading leaders' minds (session summary). Retrieved 17 September 2010 from http://www.weforum.org/en/knowledge/Events/2010/AnnualMeetingoftheNewChampions/ KN_SESS_SUMM_32351?url=/en/knowledge/Events/2010/AnnualMeetingoftheNewChampions/ KN_SESS_SUMM_32351.

World Economic Forum. (2011). Annual Meeting 2011 programme. Retrieved 23 January 2011 from http://www3.weforum.org/docs/AM11/WEF_AM11_PublicProgramme.pdf.

Yousuf, H. (2009). No 2009 pay for Bank of America CEO Ken Lewis. CNN.com, 16 October. Retrieved 15 October 2010 from http://money.cnn.com/2009/10/15/news/companies/bofa_lewis_salary/index.htm. 